January 2006

\title{
The Section 83(b) Election for Restricted Stock: A Joint Tax Perspective
}

Michael S. Knoll

\section{Recommended Citation}

Michael S. Knoll, The Section 83(b) Election for Restricted Stock: A Joint Tax Perspective, 59 SMU L. REV. 721 (2006)

https://scholar.smu.edu/smulr/vol59/iss2/11

This Article is brought to you for free and open access by the Law Journals at SMU Scholar. It has been accepted for inclusion in SMU Law Review by an authorized administrator of SMU Scholar. For more information, please visit http://digitalrepository.smu.edu. 


\title{
The Section 83(b) Election for Restricted Stock: A JoInt Tax Perspective
}

\author{
Michael S. Knoll*
}

\section{INTRODUCTION}

I

N 2003, General Electric, one of the most financially sophisticated companies in the world, and Microsoft, by almost any measure the largest user of equity-based pay, both announced that they would stop granting stock options to their employees and begin to replace their grants of employee stock options (ESOs) with grants of restricted stock. ${ }^{1}$ Two years later, in 2005, the Financial Accounting Standard Board (FASB) gave restricted stock a big boost by requiring firms that issue ESOs to treat the market value of those options as an expense on their financial statements. ${ }^{2}$ Previously, public companies treated ESOs as a costless form of compensation on their income statements, which gave ESOs a large advantage over other forms of equity-based pay. ${ }^{3}$ FASB's action, which had been under consideration for several years, has precipitated a large scale rethinking and restructuring of equity-based pay. ${ }^{4}$

According to a July 2005 survey of 340 public and private companies by Deloitte Consulting, seventy-five percent of survey respondents said their companies are reducing or already have reduced the number of options granted. ${ }^{5}$ And according to Deloitte, among the eighty-nine percent of public companies that are actively considering alternatives to ESOs, ninety-two percent listed restricted stock as their first choice. ${ }^{6}$ Although

* Theodore Warner Professor, University of Pennsylvania Law School, and Professor of Real Estate, The Wharton School, University of Pennsylvania. I thank Richard Bonfatto, Dhammika Dharmapala, Mitchell Kane, Reed Shuldiner, and David Walker for their comments and suggestions, Alvin Dong for his assistance with the research, and Christopher Hannah for inviting me to participate in this symposium in honor of Charles O. Galvin, the former dean of SMU's Dedman School of Law. This Article, and much of my scholarship, follows in Dean Galvin's pioneering path of bring tax scholarship and tax practice together. Copyright 2006 by Michael S. Knoll. All rights reserved.

1. Brian J. Hall, Transferable Stock Options (TSOs) and the Coming Revolution in Equity-Based Pay, 16 J. ApPlied Corp. Fin. 8, 8, 9 (2004).

2. Deloitte Consulting, Options Take a Hit, But What Will Take Their Pl_ACE? 1 (2005), http://www.deloitte.com/dtt/cda/doc/content/US_TMT_StockCompSurvey-071205v2(1).pdf.

3. Id. at 4 .

4. Id.

5. Id. at 2.

6. Id. 
not much data has been published on the use of restricted stock, mounting evidence shows that restricted stock is growing rapidly and is on its way to becoming, along with ESOs, one of the two dominant forms of equity-based pay. ${ }^{7}$

The most detailed data I have seen on restricted stock grants come from Mercer Human Resource Consulting. In conjunction with the Wall Street Journal, Mercer produces an annual report on chief executive officer (CEO) compensation. For 2004, Mercer analyzed the proxy statements of 350 of the largest U.S. public companies. According to Mercer, 104 CEOs received stock grants in 2002, compared to 138 in 2003 and 166 in 2004 - a $59.6 \%$ jump over the period. ${ }^{8}$ As a percentage of long-term incentive pay (which includes stock options and performance units/shares in addition to restricted stock), restricted stock jumped from $12 \%$ in 2002 to $20 \%$ in 2003 and increased further to $23 \%$ in 2004.9

Of course, Mercer's study is limited to CEO compensation. The data are sparse and preliminary, but even more striking, for total grants. According to unpublished data provided to me by Pearl Meyer \& Partners, there has been a tenfold increase in restricted stock grants at large companies from 2000 to $2005 .{ }^{10}$ Relative to the number of shares covered by option grants, restricted stock grants still cover only about $10 \%$ as many shares. ${ }^{11}$ However, restricted shares are worth more than options on an equivalent number of shares because there is no exercise price. Assuming that a typical option grant is worth between one-third and one-half as much as a corresponding restricted stock grant, restricted stock grants at large companies account for about $15 \%$ to $20 \%$ of as much compensation as ESOs.

Restricted stock is employer stock granted to an employee as part of her compensation. Although nominally owned by the employee, the stock is subject to the condition that if the employee leaves the firm within a period of time, usually three years, the stock will revert to the employer. ${ }^{12}$ Under $\S 83(\mathrm{a})$ of the Internal Revenue Code, restricted stock is neither taxable to the employee nor is it deductible by the employer when granted. ${ }^{13}$ Until the condition lapses and the stock vests, the stock is considered subject to a substantial risk of forfeiture, and thus not yet taxable. ${ }^{14}$ Only when the stock vests is the employee taxed on the

7. For evidence and arguments along these lines, see Brian J. Hall, Six Challenges in Designing Equity-Based Pay, 15 J. Applied Corp. Fin. 21, 30-31 (2003).

8. Wall St. J./Mercer Human Resource Consulting, 2005 CeO CompensaTION SURVEY AND TRENDS 2 (2005).

9. Id.

10. Pearl Meyer \& Partners, unpublished data (on file with author) (from 2004 to 2005 restricted stock grants increased from $0.01 \%$ to $0.1 \%$ of outstanding shares of 200 top companies.

11. Id. (in 2005, stock option grants were equivalent to $1.1 \%$ of outstanding shares).

12. Myron S. Scholes et al., Taxes and Business Strategy: A Planning ApPROACH 221 (3d ed. 2005).

13. I.R.C. \& 83(a), (c)(1), (h) (LEXIS 2006).

14. Id. $\S 83(\mathrm{c})(1)$. 
grant. Once that happens, she must include in her ordinary income for the tax year that includes the vesting date the fair market value of the stock as of that date less any payments she made to her employer in exchange for the stock. ${ }^{15}$ Also, only once the stock has vested does the employer receive a deduction. ${ }^{16}$ The employer can deduct in its tax year that includes the vesting date the same amount that the employee includes. ${ }^{17}$

As stated above, the general rule in $\S 83(\mathrm{a})$ says that no tax consequences flow from the restricted stock grant until the risk of forfeiture lapses. There is, however, an important exception to that rule: $\S 83$ (b) allows the employee to make an election, within thirty days of receiving the stock, to treat the restricted stock as if it is not subject to forfeit and thus to include it in income immediately. ${ }^{18}$ If the employee makes that election, she includes in her ordinary income for the tax year that includes the grant date the market value of the stock (ignoring the risk of forfeiture) as of the grant date less any payments she made for the stock. ${ }^{19}$ The employee then has a basis in her shares equal to the grant price, and any subsequent gain or loss is capital and taxed upon realization. ${ }^{20}$ The employee then has no tax consequences if and when the stock subsequently vests.

The employee's $\S 83$ (b) election also affects the employer. If the employee makes the election, the employer receives its deduction in the tax year that includes the grant date. ${ }^{21}$ Because $\$ 83(\mathrm{~h})$ provides that the employer's deduction matches the employee's inclusion, ${ }^{22}$ the employer's deduction equals the market value of the stock (ignoring the risk of forfeiture) as of the grant date. ${ }^{23}$ The employer then has no tax consequences if and when the stock subsequently vests. Table 1 summarizes the tax treatments to the employer and the employee of a grant of restricted stock.

As the discussion above suggests, the $\S 83(\mathrm{~b})$ election for restricted stock raises a range of tax planning issues for both employees and employers. So far, consultants and commentators have largely ignored these issues. Typically they just describe the tax treatment of restricted stock under $\S 83(\mathrm{a})$ and (b). Occasionally they go a little further and offer simple advice on when the election is appropriate. ${ }^{24}$ But such advice is rarely

15. Id. $\S 83(\mathrm{a})$.

16. $I d . \S 83(\mathrm{~h})$.

17. Id. The employer treats the stock grant as additional compensation paid to its employee.

18. Id. § 83(b).

19. Id.

20. Treas. Reg. § 1.83-2(a) (1978).

21. Id. $\S 1.83-6(\mathrm{a})$.

22. I.R.C. $\S 83(\mathrm{~h})$.

23. Id. $\S 83(\mathrm{~b})$.

24. See, e.g., Jeffery S. Bortnick \& Philip S. Gross, The Advantages of the Section 83(b) Election Can Be Significant, 86 J. OF TAX'N, 39 (1997); Albert Ellentuck, Case Study: Computing the Tax of a Section 83(b) Election, THE TAX Advisor 471 (July 2002); David Kaut- 
TABLE 1

TAX TREATMENT OF EMPLOYEE AND EMPLOYER FROM GRANT OF RESTRICTED STOCK (AT GRANT AND AT VESTING)

\begin{tabular}{|c|c|c|}
\hline & Section $83(a)$ & Section $83(b)$ \\
\hline Employee & $\begin{array}{l}\text { Employee is taxed when the } \\
\text { stock vests at ordinary rates } \\
\text { on the excess of fair market } \\
\text { value over price paid. }\end{array}$ & $\begin{array}{l}\text { Employee is taxed when the } \\
\text { stock is granted at ordinary } \\
\text { rates on the excess of fair } \\
\text { market value over price } \\
\text { paid. That produces a basis } \\
\text { equal to fair market value; } \\
\text { any subsequent gain or loss } \\
\text { is capital. }\end{array}$ \\
\hline Employer & $\begin{array}{l}\text { Employer receives a tax } \\
\text { deduction when the stock } \\
\text { vests in an amount that is } \\
\text { equal to the employee's } \\
\text { inclusion. }\end{array}$ & $\begin{array}{l}\text { Employer receives a tax } \\
\text { deduction at grant in an } \\
\text { amount equal to the } \\
\text { employee's inclusion. }\end{array}$ \\
\hline
\end{tabular}

based on a systematic analysis. In this Article, I develop a framework to address the tax planning issues raised by the $\S 83(\mathrm{~b})$ election and provide such a systematic analysis. ${ }^{25}$

I have divided these tax planning issues into two broad categories. The first set of issues concerns the desirability of making the $\S 83(\mathrm{~b})$ election. Although the statutory scheme nominally leaves the election to the employee, the employer can, as a condition of the grant, require the employee either to make or to refrain from making the election (or it can pay the employee either to make or not to make the election). Among the questions thereby raised by the $\S 83(\mathrm{~b})$ election are the following: Should employers leave to their employees the decision whether to make the $\S 83(\mathrm{~b})$ election? If not, should they prohibit or require the election as a condition of the grant? If employers should not always take the same position, under what circumstances should they take which ones? Assuming the employee has the choice, should the employee make the $\S 83(\mathrm{~b})$ election, and if so, under what circumstances? Are the interests of the employee and the employer in making the election ever in conflict, and if so under what circumstances? If they are in conflict, are the parties jointly better off if the grant requires the employee to make the election, prohibits the election, or just leaves the choice to the employee? The answers to these questions have substantial implications for employees

ter \& Lorraine Bell, Section 83(b) Election Offers Tax Planning Opportunities for Restricted Stock, 4 J. OF TAX'N OF EMP. BeNEFITS 77 (1996).

25. My analysis in this Article is under the regular U.S. federal income tax only. I have thus ignored the alternative minimum tax (both corporate and individual), payroll taxes, and the possibility of cross-border transactions. I have also ignored I.R.C. $\S 162(\mathrm{~m})$, which prevents corporations from deducting more than $\$ 1$ million in pay to any single executive unless certain requirements are met, and I.R.C. $\$ 409 \mathrm{~A}$, which imposes an additional tax on deferred compensation that does not meet its requirement. Those issuesalthough potentially significant-must wait for another opportunity. 
deciding whether to make the election and for employers in designing their grant programs.

The second group of issues concerns a real option element that arises in connection with the $\S 83(\mathrm{~b})$ election. Section $83(\mathrm{~b})(2)$ allows the employee thirty days from the grant date to make the election. ${ }^{26}$ If the employee makes the election, she pays tax on the value of the stock as of the grant date, not as of the election date. Thus, the employee can wait thirty days and see what happens to her employer's stock price before deciding whether to make the election, which is effected at old (grant date) prices. The relevant questions here include the following: Under what circumstances should the employee exercise the option? How valuable is the option to wait to the employee? How much does the option cost the employer? And are there alternative financial contracts that could be offered that would be more attractive to the employer and the employee than the $\S 83(\mathrm{~b})$ election?

In studying the tax consequences of restricted stock in general, I have emphasized a joint tax planning approach. A joint perspective is appropriate--even for the $\S 83(\mathrm{~b})$ election, which nominally belongs to the employee-because the employer designs the grant program, and thus can decide whether to require, prohibit, or permit the election. This Article thus follows the methodology developed by Merton Miller and Myron Scholes. ${ }^{27}$ Surprisingly, the two most sophisticated theoretical treatments of the $\S 83$ (b) election-Robert McDonald's 2003 working paper ${ }^{28}$ and Scholes et al.'s, Taxes and Business Strategy ${ }^{29}$-both look at the $\S 83$ (b) election from the perspective of the employee alone. Thus, neither one takes the joint perspective that I do and that is appropriate here.

In addition, because the $\S 83(\mathrm{~b})$ election has tax as well as non-tax consequences, I have tried to be careful in making judgments about the tax consequences. The method I use endeavors to make an apples-to-apples comparison by isolating the tax consequences of the $\S 83(\mathrm{~b})$ election. I accomplish that by employing a heuristic device that eliminates the effects of the $\S 83(\mathrm{~b})$ election on non-tax factors, such as before-tax cash flow, investment, capital structure and risk. I assume that the employer and employee engage in offsetting transactions that eliminate the non-tax differences from making the $\S 83$ (b) election, so that the only difference between two otherwise identical series of transactions is taxes. Only after I have made such an apples-to-apples comparison will I discuss the tax consequences of making the $\S 83(\mathrm{~b})$ election when there are no offsetting transactions.

26. See Treas. Reg. $\S 1.83-2$ (b).

27. Merton H. Miller \& Myron S. Scholes, Executive Compensation, Taxes, and Incentives, in Financial Economics' Essays in Honor of Paul CoOtner 190-201 (1982).

28. Robert L. McDonald, Is It Optimal to Accelerate the Payment of Incomes Tax on Share-Based Compensation? (Working Paper, Sept. 19, 2003), available at http://www.kellogg.northwestern.edu/faculty/mcdonald/htm/opexer.pdf.

29. See SCHOles ET AL., supra note 12. 
A final introductory matter remains. One planning question logically precedes the question of how should an employer design its restricted stock program to maximize the benefits to both it and its employees. That is the question: Should the employer offer restricted stock as part of its compensation packages? I previously addressed that question. ${ }^{30}$ Under reasonable assumptions, I showed that granting restricted stock is at least as efficient from a tax perspective as paying additional cash compensation. ${ }^{31}$ Thus, that earlier article answered the threshold question of the desirability of using restricted stock in the affirmative, thereby setting the stage for this Article. ${ }^{32}$

\section{THE SECTION 83(b) ELECTION}

Although $\S 83(\mathrm{~b})$ vests only the employee with the power to make the election, the employer can-as a condition of the grant-require the employee either to make or to refrain from making the election. ${ }^{33}$ The employer can also pay the employee either to make or not make the election. Jennifer Blouin and Mary Ellen Carter have shown that the inclusion of such limitations on restricted stock grants, although rare, do occur. $^{34}$ Most employers, however, take a laissez-faire approach to the $\S 83(\mathrm{~b})$ election. ${ }^{35}$ They neither require nor prohibit the election as a condition of the grant, nor will they pay the employee to make or not make the grant; they simply leave that choice to the employee. ${ }^{36}$

Surprisingly, little data exist on how many employees make the election. The only discussions I could find were anecdotal. Robert McDonald provides several examples where employees made the election. ${ }^{37}$ And David Walker states as follows:

Mature public companies and start-up companies use restricted stock in different ways. Public companies typically make outright grants of restricted stock to their employees as compensation, generally in combination with or as an alternative to stock options. Only rarely are public company employees asked to pay anything for restricted stock, and they are virtually never asked to pay fair market value. Here, the disadvantages of a $\S 83(\mathrm{~b})$ election-immediate taxation and risk of forfeiture and non-recovery of tax-loom large, and the election is rarely made. By contrast, early stage start-up companies often sell shares to key employees at a nominal value, which can be argued to be the fair market value of the stock in the fledgling ven-

30. See generally Michael S. Knoll, The Tax Efficiency of Stock-Based Compensation, 103 TAX Notes 203 (2004).

31. Id. at 210 .

32. See also David I. Walker, Is Equity Compensation Tax Advantaged?, 84 B.U. L. REV. 695 (2004) (reaching a similar conclusion).

33. See Jennifer L. Blouin \& Mary Ellen Carter, Restricted Stock and Section 83(b)

Elections 3 (Working Paper, June 2006).

34. Id. at $12-13$.

35. Id.

36. Id.

37. McDonald, supra note 28 , at 2-3. 
ture. Thus, employees of start-ups can make a $\$ 83(\mathrm{~b})$ election and incur little or no current tax, and they generally do. ${ }^{38}$

The rest of this part focuses on whether it is in the joint interest of the employer and the employee for the employee to make the election. The argument proceeds in stages. I first consider a base case with numerous simplifying assumptions, and then I relax those assumptions.

\section{A. The Base Case}

I start with the following simplifying assumptions: Consider a public company with income tax rate, $t$, that is assumed (for now) to be constant over time. The company grants an employee one share of stock, which she will forfeit back to the company if she leaves its employ before it vests. Denote the date of the grant as $T=0$, and the date the share will vest as $T=1$. Denote the price of the employer's stock at the time of the grant as $P_{0}$ and at the time the grant vests as $P_{1}$. The stock does not pay dividends. Assume that the employee has a personal tax rate on ordinary income of $t_{\mathrm{P}}$, a personal tax rate on long-term capital gains of $t_{\mathrm{CG}}$, and that both tax rates are assumed (for now) to remain constant over time. ${ }^{39}$

\section{Employer}

To simplify the discussion, I have generally assumed throughout this Article that the employer and the employee close out their transactions at the vesting date. ${ }^{40}$ The employee sells her restricted stock at that time, and the employer repurchases it. Consider the employer first. If the employee does not make the election, when the stock vests the employer will have one additional share outstanding (assuming that the employee did not forfeit her share). In addition, until vesting there will have been no tax consequences and thus no cash flow consequences to the employer from the grant. When the shares vest, the employer deducts the current market value of the granted stock $\left(P_{1}\right)$, which reduces its tax liability by $t P_{1}$, and pays $P_{1}$ to repurchase the stock. Denote the after-tax cash that the employer has at vesting as a result of the grant when the employee does not make the election by $C_{E R}^{N}$. The superscript $N$ is used to indicate that there is no election (a superscript $E$ will be used when there is an election) and the subscript $E R$ is used to denote the employer (a subscript $e e$ will be used for the employee). Thus, the employer's after-tax cash at vesting when the employee does not make the election is given by the following expression:

$$
C_{E R}^{N}=-(1-t) P_{1}
$$

where the minus sign indicates an outflow of cash.

38. Walker, supra note 32 , at 707 (citations omitted).

39. Later on, I relax the assumption of constant tax rates.

40. This assumption is not necessary to reach the results I report, but it simplifies both the arithmetic and the exposition. In addition, it is straightforward how to adjust the formulas for a later disposition. 
Alternatively, if the employee makes the $\S 83($ b) election, the employer will receive an immediate deduction equal to the market price of one share. Thus, at the grant date, the employer will receive a deduction of $P_{0}$, which will reduce its current taxes by $t P_{0}$. The employer's cash flow at vesting will depend in part on how it invests its tax savings. Denote the employer's after-tax return on its tax saving by $x$. At vesting, the employer will have cash on hand as a result of the grant of $t P_{0}(1+x)$. It will also cost the employer $P_{1}$ to repurchase the share. Thus, the employer's cash outflow at vesting if the employee makes the election, $C_{E R}^{E}$, is as follows:

$$
C_{E R}^{E}=-P_{1}+t P_{0}(1+x) \text {. }
$$

A simple comparison of equations (1) and (2) illustrates the logic underlying the frequent observation of commentators and consultants that the employer is worse off as a result of the election if its stock has increased sharply and better off if it has fallen or risen only slightly. ${ }^{41} \mathrm{Al}$ though that observation is accurate, as far as it goes, it cannot justify the conclusion-often advanced-that the election hurts the employer if the price of its stock rises substantially. That is because the employer can easily neutralize the tax and non-tax effects of the employee's election by investing its tax savings in its own stock. ${ }^{42}$ If the employer then sells that stock at vesting, it will be in exactly the same position as it would have been if the employee had not made the election. ${ }^{43}$

Accordingly, assume that the employee makes a $\S 83(\mathrm{~b})$ election and the employer purchases $t$ shares of its own stock with a cash inflow from the election of $t P_{0} .{ }^{44}$ When the restricted shares vest, the employer sells the purchased shares for $t P_{1}$. Section 1032 provides that a corporation is not taxed on the gain or loss it realizes from dealings in its own stock..$^{45}$ Thus, after the sale, the employer has additional cash of $t P_{1}$. Also, at vesting, the employer repurchases the share it previously granted its employee at a cost of $-P_{1}$. The net out-of-pocket cost to the employer then is $-(1-t) P_{1}$, which is also the amount given by equation (1). It therefore follows that the employer's cash flow is unaffected by the employee's decision whether to make the $\$ 83(\mathrm{~b})$ election. ${ }^{46}$

41. The employer is hurt by the employee's election $\left(C_{E R}^{N}>C_{E R}^{E}\right)$ if the employer's stock price over the vesting period rises faster than the investment the employer makes with the tax savings generated by the election, $P_{1}>P_{0}(1+x)$. Conversely, the employer benefits from the election $\left(C_{E R}^{E}>C_{E R}^{N}\right)$ if its stock price does not rise as fast as its investment, $P_{1},<P_{0}(1+x)$.

42. The discussion in this part ignores the possibility that the stock has appreciated between the grant date and the exercise date. That possibility is taken up in Part III, infra.

43. If the employer invests in its own stock, its return $x$ will be $\left(P_{1}-P_{0}\right) / \mathrm{P}_{0}$. Substituting that expression for $x$, equation (2) simplifies into equation (1).

44. Because I assume that the employer grants the employee one share of stock, the purchase of $t$ shares is necessarily the purchase of a fraction of a share. More generally, if the employer grants the employee $n$ shares, the employer would purchase $n t$ shares.

45. I.R.C. \& 1032(a) (2005).

46. The non-tax consequences are also the same with and without the election because the employer has outstanding 1-t net shares. Without the election, the employer has one share outstanding to its employee and a future deduction worth $t$ shares. With the election, 
An example might help to illuminate the intuition. Suppose Max Co. grants Ruby 100 shares of restricted Max Co. stock on July 1, 2004, when Max Co.'s stock price is $\$ 10$ a share. The shares vest on July 1, 2007. Max Co.'s tax rate is $35 \%$; Ruby's tax rates are $35 \%$ on ordinary income and $15 \%$ on capital gains. If Ruby does not make the $\S 83(\mathrm{~b})$ election, Max Co. is entitled to a deduction equal to the market value of 35 shares of Max Co. stock when the grant vests on July 1, 2007. Thus, if Max Co. repurchases 100 shares at that date, it will be out-of-pocket the price of 65 shares. (That is true regardless of the price of Max Co.'s stock on that date.) Alternatively, if Ruby makes the $\S 83(\mathrm{~b})$ election, then Max Co. receives a $\$ 1000$ deduction in 2004 that reduces its taxes by $\$ 350$. Max Co. can then offset the effect of Ruby's election on its cash flow by using the $\$ 350$ to purchase 35 shares of Max Co. stock. Max Co. then will have 100 shares outstanding from the grant and 35 shares in its treasury (which shares are outstanding when Ruby does not make the election). Upon vesting, Max Co. can repurchase 65 shares in the market. The cash flow consequences to Max Co. are therefore the same whether or not Ruby makes the election regardless of Max Co.'s stock price at vesting.

Two results follow from the above demonstration that the employer can neutralize the tax consequences of the employee's election. First, the received wisdom - that the election hurts the employer if its stock price rises substantially over the vesting period, and conversely-is wrong. The election generally has no effect on the employer. Second, the overall tax efficiency of the $\S 83$ (b) election generally depends only upon the tax consequences to the employee.

\section{Employee}

Turning now to the employee, assume she does not make the $\S 83(\mathrm{~b})$ election. There are then no cash flow consequences to the employee at grant. At vesting, she will pay tax of $t_{P} P_{1}$. If she sells her stock immediately after vesting, she will receive $P_{1}$. Thus, the employee's after-tax cash at vesting when she does not make the election is given by:

$$
C_{E E}^{N}=\left(1-t_{P}\right) P_{1}
$$

Alternatively, if she makes the $\S 83(\mathrm{~b})$ election, she will pay tax of $t_{P} P_{0}$ at grant, and she will have a basis of $P_{0}$ in her one share. If she sells her share at vesting, receiving income of $P_{1}$, she will pay capital gains taxes on the appreciation that occurs from grant to vesting, $-t_{C G}\left(P_{1}-P_{0}\right),{ }^{47}$ and so her after-tax cash is given by:

$$
C_{E E}^{E}=\left(1-t_{C G}\right) P_{1}+t_{C G} P_{0}
$$

the employer has one share outstanding to its employee, but $t$ fewer shares outstanding to other investors.

47. If she does not sell the stock then, but at a later date, the qualitative results are unchanged except that the effective capital gains tax rate as of the vesting date replaces the statutory capital gains tax rate. 
Although tempting, it would not be appropriate to draw any conclusions about the desirability of the $\S 83$ (b) election by comparing equations (3) and (4). That is because the employee has a cash outflow at grant with the election-equation (4) - but no corresponding outflow with no election-equation (3).

In order to match the cash flow at grant when she does not make the election to the cash flow when she does make the election, the non-electing employee must do something with the cash that the electing employee uses to pay her taxes. ${ }^{48}$ Assume the non-electing employee deposits in a bank account all of the money the electing employee uses to pay the tax due as a result of the election. Assume further that the non-electing employee liquidates that account when the grant vests. Also, assume an after-tax interest rate of $r$. At vesting, then, the non-electing employee receives $t_{P} P_{0}(1+r)$ when she liquidates her bank account. She also sells her share immediately after it vests, paying ordinary income tax on the value of the stock at vesting. Thus, upon sale, the non-electing employee will pay tax of $t_{P} P_{1}$. Hence, as a result of the grant, the non-electing employee will have the same cash flow consequences at the grant date as the electing employee. Upon sale, the non-electing employee's after-tax cash flow as a result of the grant is as follows:

$$
C_{E E}^{N, A}=\left(1-t_{P}\right) P_{1}+t_{P} P_{0}(1+r),
$$

where the superscript $A$ following the superscript $N$ indicates that an adjustment at the grant date was made so that the cash flow at grant with no election $(N)$ equals the cash flow at grant with the election $(E)$. Specifically, in equation (5) the adjustment is for the non-electing employee to deposit in a bank account all of the proceeds she would have used to pay the tax if she had made the election.

Whether the employee is better off making the election is still unclear. Her wealth depends upon the stock price $\left(P_{1}\right)$ at vesting. For high prices she is better off with the election, but for low prices she is better off without it. ${ }^{49}$ Does that mean that she should make the election if she expects a substantial increase in price? Not necessarily. ${ }^{50}$

That is because the economics of the two transactions are not equivalent. Most noticeably, the employee who has made the election has increased her exposure to her employer's stock. In order to quantify

48. In effect, a simple comparison of equations (3) and (4) implicitly assumes that the non-electing employee discards cash on the grant date equal to the cost of the election.

49. The employee's wealth at vesting if she makes the election-equation (4)-exceeds her wealth if she does not make the election and deposits the difference in a bank account-equation (5) - when $\left.P_{1}>\left[\left(t_{p}(1+r)\right)-t_{C G}\right) /\left(t_{p}-t_{C G}\right)\right] P_{0}$.

50. Equation (5) is similar to the models recently developed by Kenneth Anderson and John Goldsbury. Kenneth Anderson, The 83(b) Election for Restricted Stock: A Decision Framework, J. of Fin. Services Prof. 59 (Sept. 2004); John Goldsbury, The Myth of the 83(b) Election, $21 \mathrm{~J}$. OF TAX'N OF INVESTMENTS 300 (2004). However, in contrast with Anderson and Goldsbury, who developed their models to assist employees in deciding whether to make the $\S 83(\mathrm{~b})$ election, I argue below that employees should not use equation (5) in deciding whether to make the election. 
the tax consequences of the election to the employee, the non-tax consequences of the election must first be eliminated.

Start with the number of shares the employee owns at the grant date. How many shares does she own? That might seem like a silly question, with an obvious answer of one share whether the employee makes the election or not. The question is actually more subtle, and the answer is not always one. Consider first what happens if the employee makes the election. The employee holds one share of stock with a basis of $P_{0}$. As the market value of the share changes, the employee's portfolio changes in value. If she were to sell her share, she would have $P_{0}$ plus the product of $\left(1-t_{C G}\right)$ and any change in price over the vesting period $\left(P_{1}-P_{0}\right)$. On an after-tax basis, the employee's exposure to her employer's stock is $\$(1-$ $t_{C G}$ ) for each $\$ 1$ change in price. That is the same exposure as has an individual who purchases one share of her employer's stock on her personal account for $P_{0}$ (and holds that share for more than one year, so any gain or loss is long-term capital). Thus, the electing employee's position is equivalent to owning one share with basis $P_{0}$.

Consider now the employee who did not make the election. She also nominally holds one share, but without any basis. Assuming she does not forfeit the stock, then at vesting, she will owe $\operatorname{tax}$ of $t_{P} P_{1}$. She does not have the same exposure to price changes as the electing employee. For the non-electing employee, each one dollar change in the price of her employer's stock translates into only an additional $\$\left(1-t_{P}\right)$ after tax, not $\$\left(1-t_{C G}\right)$.

We could describe the non-electing employee's stock ownership in two ways. First, and most intuitively, we could say that the employee owns $\left(1-t_{P}\right)$ shares that are not subject to further tax until vesting. ${ }^{51}$ Her position in her company's stock then is the same as holding $\left(1-t_{P}\right)$ shares in a Roth IRA and withdrawing those shares at the vesting date. ${ }^{52}$ Second, we could describe the non-electing employee's stock ownership in terms of an investor who bought the employer's shares on personal account at a share price of $P_{0}$. Compared to such a shareholder, the non-electing employee holds the equivalent of $\left(1-t_{P}\right) /\left(1-t_{C G}\right)$ shares. That is because an investor who purchased $\left(1-t_{P}\right) /\left(1-t_{C G}\right)$ shares at $P_{0}$ would see her after-tax wealth increase by $\left(1-t_{P}\right)$ for each dollar increase in stock price. ${ }^{53}$ In contrast to such a purchaser, however, the non-electing employee has a basis of 0 in her shares. ${ }^{54}$ Thus, at vesting, the non-electing employee will receive $\left[\left(1-t_{P}\right) t_{C G} /\left(1-t_{C G}\right)\right] P_{0}$ less than the purchaser of $\left(1-t_{P}\right) /\left(1-t_{C G}\right)$ shares.

51. Any gains or loses that occur on her $1-t_{P}$ shares after vesting would be subject to tax as capital gain or loss.

52. That is, of course, equivalent to holding 1 share in a regular individual retirement account ("IRA") and being subject to an ordinary income tax rate of $t_{P}$. That equivalence assumes that the taxpayer will withdraw her employer stock from both IRA accounts at the same date (vesting date) and that her tax rate is the same at both grant and vesting dates.

53. The denominator reflects the capital gains tax that the purchaser would pay when she sells her shares (assumed to be at the vesting date).

54. A purchaser who purchased $\left(1-t_{p}\right) /\left(1-t_{C G}\right)$ shares at a price of $P_{0}$ per share would have a basis of $\left[\left(1-t_{p}\right) /\left(1-t_{C G}\right)\right] P_{0}$ in her shares. 
In other words, the non-electing employee can be viewed as owning (1$\left.t_{P}\right) /\left(1-t_{C G}\right)$ shares and owing $\left[\left(1-t_{P}\right) t_{C G} /\left(1-t_{C G}\right)\right] P_{0}$ at vesting.

In effect, then, by making the election, the employee has increased her exposure to changes in the price of her employer's stock. Before the election she would earn 1-t $t_{P}$ after-tax dollars for each dollar change in price. After the election that figure rises to $1-t_{C G}$. Although the election does not change the number of shares she legally owns (one), it does change her economic exposure. The employee economically owns more stock after the election (one share) than before $\left(\left(1-t_{P}\right) /\left(1-t_{C G}\right)\right.$ shares). Although it is usually not phrased this way, from the employee's perspective, the election is equivalent to purchasing additional shares of the employer's stock. In effect, the employee, by making the election, has purchased $\left(t_{P}-t_{C G}\right) /\left(1-t_{C G}\right)$ additional shares. The election then is more than a tax decision. It is also an investment decision, with the attendant cash flow and risk exposure consequences that an additional investment by the employee in her employer's stock ordinarily entails. ${ }^{55}$ Expressed differently, the employee, through the election, increases her economic ownership of her employer's stock even though she holds title to the same one share both before and after the election. ${ }^{56}$

Because the election has non-tax consequences, the tax consequences of the election cannot be gleaned without first equalizing the employee's economic investment in her employer's stock. Instead of purchasing $\left(t_{P}-t_{C G}\right) /\left(1-t_{C G}\right)$ shares indirectly, through the election, the employee could have purchased those shares directly in the market. Buying the additional shares directly would have cost her $\left[\left(t_{P}-t_{C G}\right) /\left(1-t_{C G}\right)\right] P_{0}$, which is less than the cost of the election $t_{P} P_{0}{ }^{57}$ With the election, the employee will have cash of $\left(1-t_{C G}\right) P_{1}$ if she sells her shares at vesting. Without the election, but with the purchase of additional shares, she will also have cash from the sale of all of her shares of $\left(1-t_{C G}\right) P_{1}$. However, because the election was more expensive than the purchase of additional shares, she will also have cash left if she does not make the election. That cash is $\left[t_{C G}\left(1-t_{P}\right) /\left(1-t_{C G}\right)\right] P_{0} .{ }^{58}$ If she puts that cash under her mattress, she will have the same amount of cash at vesting (after selling her stock), regardless of the price of her employer's stock at that date. ${ }^{59}$ In that case,

55. For a typical employee, who is already too heavily invested in her employer, these non-tax consequences are likely to be mostly negative.

56. Obviously, there would be no reason for the employee to make the election if there was no capital gains preference, $t_{p}=t_{C G}$, and the increased exposure would be greatest if $t_{C G}=0$. As long as there is a capital gain preference, $t_{p}>t_{C G}$, the election increases the employee's exposure.

57. The inequality holds when the individual tax rate on ordinary income is less than $100 \%\left(t_{p}<1\right)$ and when there is a capital gain preference for individuals $\left(0<t_{C G}<t_{p}\right)$.

58. Given current statutory tax rates, in order to match her economic exposure from the election, the employee will have to purchase $0.24[=(35 \%-15 \%) /(1-15 \%)]$ shares. The cost to the employee of purchasing these additional shares is $0.24 P_{0}$. That is less than the cost to the employee of making the election, $0.35 P_{0}$. That leaves the employee who does not make the election with an additional $0.11 P_{0}$ to invest.

59. The equivalence of the two positions can be demonstrated as follows: If the employee makes the election and sells her stock when it vests, she will receive $P_{1}$, pay taxes of 
whether she makes the election or not, her after-tax wealth will be $C_{e e}^{e}=\left(1-t_{C G}\right) P_{1}+t_{C G} P_{0}$, which is equation (4).

Of course, the non-electing employee can make a better investment with her excess cash than to stuff it under her mattress. If she simply deposits her excess cash in a bank account until the vesting date, her after-tax wealth at vesting will be:

$$
C_{E E}^{N, A^{\prime}}=\left(1-t_{C G}\right) P_{1}+t_{C G} P_{0}+t_{C G}\left[\left(1-t_{P}\right) /\left(1-t_{C G}\right)\right] P_{0} r,
$$

where the superscript $A^{\prime}$ after the superscript $\mathrm{N}$ indicates that the nonelecting employee's cash flow at grant and her exposure to her employer's stock are matched to the cash flow and exposure of the electing employee (E).

The difference then between equations (4) and (6) is the difference in the employee's after-tax wealth from making the $\S 83(\mathrm{~b})$ election as compared with not making the election. The electing employee will have additional cash, denoted $\Delta$, at vesting as follows:

$$
\Delta=-t_{C G}\left[\left(1-t_{P}\right) /\left(1-t_{C G}\right)\right] P_{0} r
$$

which is always negative (for tax rates below 100 percent). Expressed in words, the non-electing employee's after-tax cash flow exceeds the electing employee's by the after-tax interest the non-electing employee earns on her incremental investment. That is to say, the cost of the election is the cost of tying up capital that could otherwise be invested and generate a return. What therefore follows is that even if the employee wants to increase her holdings of her employer's stock, she still should not make a $\S 83(\mathrm{~b})$ election. She has a dominant strategy that involves purchasing additional stock. ${ }^{60}$

The intuition for why the election hurts the employee is most easily grasped by going back to the more intuitive of the two answers to the question how many shares does the non-electing employee hold. That

$t_{C G}\left(P_{1}-P_{0}\right)$ and be left with $\left(1-t_{C G}\right) P_{1}+t_{C G} P_{0}$. If she does not make the election and sells all of her shares when her original share vests, she will receive $P_{1}$ for her original share and pay taxes of $t_{p} P_{1}$. She will also sell $\left(t_{p}-t_{C G}\right) /\left(1-t_{C G}\right)$ shares for $\left[\left(t_{p}-t_{C G}\right) /\left(1-t_{C G}\right)\right] P_{1}$ and pay taxes of $t_{C G}\left[\left(t_{p}-t_{C G}\right) /\left(1-t_{C G}\right)\right]\left(P_{1}-P_{0}\right)$, leaving her with $\left(1-t_{C G}\right) P_{1}+\left[t_{C G}\left(t_{p}-t_{C G}\right) /\left(1-t_{C G}\right)\right] P_{0}$. Added to that is $\left[t_{C G}\left(1-t_{p}\right) /\left(1-t_{C G}\right)\right] P_{0}$ that she has in her mattress. Together, if she does not make the election, but instead buys additional shares, she has $\left(1-t_{C G}\right) P_{1}+t_{C G} P_{0}$, exactly what she has when she makes the election.

60. In theory, instead of assuming that the non-electing employee purchases additional shares, I could have assumed that the electing employee sells shares short. That would match the non-tax consequences of making the election to those of not making the election. In the text, I match the non-tax consequences of not making the election to those of making the election. I did not use the short sale for several reasons. First, many firms discourage employees from engaging in short sales. Second, the transaction costs for short sales can be large. Third, there is a possible tax arbitrage from shorting and holding the same stock if the short side receives ordinary treatment and the long side receives capital treatment. That possibility has led to the development of anti-abuse rules for short sales that complicate the tax analysis. Because of those anti-abuse rules, the tax consequences of the election are not being isolated from those of the anti-abuse rule. If, however, the short side receives the same capital treatment as the long side, then the election with a short sale could be compared to not making the election. 
answer was that the electing employee's position is equivalent to owning $\left(1-t_{P}\right)$ shares that are not subject to tax (until vesting). ${ }^{61}$

Using that intuition, the election converts the employee's investment in $\left(1-t_{P}\right)$ shares of employer stock that is free from tax until vesting into an investment in one share of stock that is taxable at the employee's capital gains tax rate on any subsequent price changes. Expressed differently, the election has two effects. First, through the election, the employee has increased her investment in her employer's stock by $t_{P}$ shares, from $\left(1-t_{P}\right)$ shares to one share. Thus, given a current ordinary income tax rate of $35 \%$, by making the election the employee increased her investment in employer stock by 0.35 shares, from 0.65 shares to one share.

Second-and this is key-the election changed the tax treatment of the employee's original investment. Without the election, the employee would have held $\left(1-t_{P}\right)$ shares that would not have been subject to tax on any price changes that occurred before vesting. With the election, those $\left(1-t_{P}\right)$ shares are now subject to tax at the long-term capital gains rate of $t_{C G}$ on such price changes. Thus, the net cost of the election is the difference between holding $\left(1-t_{P}\right)$ shares tax free until vesting compared with holding the same shares subject to capital gains taxes. Denote the expected before-tax rate of return by $R$ and assume the employee cashes out her investments at vesting. The electing employee will have additional cash at vesting in the following amount:

$$
\Delta=-\left(1-t_{P}\right) P_{0} R t_{C G},
$$

which is negative (for tax rates below $100 \%$ ). In words, the cost to the employee of the election is that she converts the return, $R$, on the aftertax grant, $\left(1-t_{P}\right) P_{0}$, from being untaxed into being taxed at the capital gains tax rate, $t_{C G}$. Therefore, in the base case, the election is inefficient for the employee and employer taken together because it imposes capital gains taxes on the employee's gain on the original grant until vesting, which gain would have escaped tax had the employee not made the election. ${ }^{62}$

Returning to the earlier numerical example, if Ruby makes the $\$ 83(\mathrm{~b})$ election she pays $\$ 350$ tax and has 100 shares with a $\$ 1,000$ basis. To match her exposure from the election, Ruby purchases 23.529 shares at a

61. Note that the employee's exemption from tax on price changes prior to vesting is an application of the widely recognized result that an immediate deduction of the cost of the investment followed by a later inclusion of the investment's full amount is equivalent to exemption of the return on the investment. In effect, $\S 83(\mathrm{a})$ can be seen as permitting the employee to take a deduction of $P_{0}$ at the grant date and an inclusion of $P_{1}$ at the vesting date. The former offsets an equivalent deduction.

62. Although it is not apparent, these two ways of expressing the cost of the electionequations (7) and (8) - are equivalent. In equilibrium, the after-tax return, $r$, should equal to the product of the before-tax return and one minus the capital gains tax rate, $\left(1-t_{C G}\right) R$. That is to say, $r=\left(1-t_{C C}\right) R$. Substituting $r /\left(1-t_{C G}\right)$ for $R$ into equation (8) yields $\Delta=\left[t_{C G}\right.$ $\left.\left(1-t_{p}\right) /\left(1-t_{C G}\right)\right] P_{0} r$, which is equation (7). Thus, the two ways of expressing the tax disadvantage from making the election are equivalent. 
cost of $\$ 235.29 .{ }^{63}$ That leaves her with $\$ 114.71$ to invest that she does not have if she makes the election. Assume that the investment generates after-tax interest at the rate of $10 \%$ over the vesting period, which comes to \$11.47. Below, I consider two possible scenarios for Max Co.'s stock price, and I show that Ruby will have $\$ 11.47$ more at vesting by not making the election regardless of what happens to Max Co.'s stock.

Consider first the possibility that Max Co.'s stock increases tenfold to $\$ 100$ a share at vesting. If Ruby made the election, she will sell her 100 shares for $\$ 10,000$, pay $\$ 1350$ in tax, and so be left with $\$ 8,650$. Alternatively, if Ruby did not make the election, but instead used part of the $\$ 350$ to purchase additional shares and deposited the rest in the bank, then Ruby still sells the original 100 shares for $\$ 10,000$ and now pays $\$ 3,500$ tax. Ruby also sells the additional 23-plus shares for $\$ 2,352.94$, and pays tax upon sale of $\$ 317.65$. Ruby also has $\$ 114.71$ in principal in her account and an additional $\$ 11.47$ in interest. Thus, Ruby has $\$ 8661.47$ in total, exactly $\$ 11.47$ more than when she made the election.

Consider now the possibility that Max Co.'s stock falls to one tenth its grant price, or $\$ 1$ a share. If Ruby made the election, she will sell 100 shares for $\$ 100$, receive a capital loss that is worth $\$ 135$, and thus end up with $\$ 235$. Alternatively, if Ruby did not make the election, but followed the strategy outlined above, she would sell her original 100 shares for $\$ 100$, pay $\$ 35$ in tax, sell her additional 23 -plus shares for $\$ 23.53$, and receive a capital loss that is worth $\$ 31.76$. Ruby also has $\$ 114.71$ in principal in the bank and $\$ 11.47$ in after-tax interest. Thus, Ruby has $\$ 246.47$, which is again exactly $\$ 11.47$ more than what she has if she makes the election.

As the example above suggests, the cost to the employee of the election is not affected by the appreciation or depreciation of the employer's stock over the vesting period. The per share cost to the employee of making the election is given by multiplying the cost of the election for one share, equation (7), by the number of shares granted $(n)$. Thus, the cost is a function of the number of shares granted $(n)$, the employee's ordinary $\left(t_{P}\right)$ and capital gains tax rates $\left(t_{C G}\right)$, and the after-tax interest rate over the vesting period $(r) .64$ The intuition is that the cost of the election is the after-tax interest that the employee can earn on the funds she does not have to invest in the employer's stock in order to match the increased exposure from the election, but that she must otherwise hold aside in order to match the cash flow at vesting. At current tax rates, that amount is about $11.5 \%$ of the market price of the restricted stock granted to the employee. ${ }^{65}$ As of March 2006, municipal bonds (with very low risk of default) pay interest (exempt from federal taxes) at an annual rate

\footnotetext{
63. The 23.529 shares are calculated as follows: $23.529=\left[\left(t_{p}-t_{C G}\right) /\right.$ $\left.\left(1-t_{C G}\right)\right] 100=[(0.35-0.15) /(1-0.15)] 100$.

64. The after-tax interest over the vesting period $(r)$ is a function of both the periodic after-tax interest rate and the vesting period. $15 \%$.

65 . Calculated with a personal income tax rate of $35 \%$ and a capital gains tax rate of
} 
of about $3.4 \%$. Returning to the example, the cost of the election, both in dollars and as a percent of the value of the grant $(\$ 1,000)$, are given in the following table.

TABLE 2

THE COST OF THE SECTION 83(B) ELECTION (AS A FUNCTION OF THE TIME TO VESTING)

\begin{tabular}{|l|c|c|c|c|c|}
\hline \multicolumn{1}{|c|}{ Years } & 1 & 2 & 3 & 4 & 5 \\
\hline Value as Percent of Grant & $-0.39 \%$ & $-0.79 \%$ & $-1.21 \%$ & $-1.64 \%$ & $-2.09 \%$ \\
\hline Value in Dollars & $-\$ 3.90$ & $-\$ 7.93$ & $-\$ 12.10$ & $-\$ 16.41$ & $-\$ 20.87$ \\
\hline
\end{tabular}

\begin{tabular}{|c|c|c|c|c|c|}
\hline Years & 6 & 7 & 8 & 9 & 10 \\
\hline $\begin{array}{l}\text { Value as Percent of Grant } \\
\text { Value in Dollars }\end{array}$ & $\begin{array}{r}-2.55 \% \\
-\$ 25.48\end{array}$ & $\begin{array}{l}-3.02 \% \\
-\$ 30.25\end{array}$ & $\begin{array}{r}-3.52 \% \\
-\$ 35.18\end{array}$ & $\begin{array}{r}-4.03 \% \\
-\$ 40.27\end{array}$ & $\begin{aligned} &-4.55 \% \\
&-\$ 45.54\end{aligned}$ \\
\hline
\end{tabular}

Negative numbers are the cost of the election; positive numbers (if there were any) would indicate a benefit.

Negative numbers are the cost of the election; positive numbers (if there were any) would indicate a benefit.

Although most of the amounts in Table 2 seem small on a $\$ 1,000$ grant, the table makes clear that the election is always costly. Moreover, Table 2 makes clear that the cost of making the election increases at an increasing rate as the time to vesting increases.

\section{B. EXTENSIONS}

The discussion and results described above-that the employee's $\S 83$ (b) election has no impact on the employer because the employer can neutralize the effect of the $\S 83(\mathrm{~b})$ election by using its tax savings to purchase shares, but that the election increases the employee's taxes because she can do better by purchasing shares than by making the election-were for the base case. The assumptions that define that case are as follows: the employer's stock is publicly traded; both the employer's and employee's tax rates are constant over time; the employee pays nothing to the employer for the restricted stock; ${ }^{66}$ the stock does not pay dividends; and the employee does not subsequently forfeit the stock back to the employer. These assumptions are likely accurate in many circumstances. However, when they are not accurate, the above results do not necessarily hold. To some of these issues I now turn.

66. Robert McDonald discusses this issue from the employee's perspective and concludes that the higher the portion of the market price paid by the employee, the greater the incentive for the employee to make the election. See McDonald, supra note 28, at 7 . Later on, in subpart II.B.4, I consider the effect of explicit payments for the stock on the $\$ 83(\mathrm{~b})$ election. 


\section{Changing Tax Rates}

In the base case, I assumed that both the employee's and the employer's tax rate are constant over the vesting period. I then used that assumption to reach the conclusion that the $\S 83(\mathrm{~b})$ election is inefficient because it increases the employee's taxes and has no impact on the employer's. When tax rates change over time, those conclusions do not necessarily follow. Under some circumstances, the election can be jointly efficient as shown below.

Start with the employer. When the employer's tax rate changes between grant and vesting, the employer's wealth is affected by the $\S 83$ (b) election because it can no longer offset the effect of the election by using the proceeds generated by that election to purchase additional shares. If the employee does not make the election, then at vesting, the employer will receive a deduction worth $t_{1} P_{1}$, where $t_{1}$ is the corporate tax rate at vesting. If the employee makes the $\$ 83(\mathrm{~b})$ election, the employer will receive an immediate deduction worth $t_{0} P_{0}$, where $t_{0}$ is the corporate tax rate at grant. If the employer then uses those proceeds to repurchase its own stock, it can buy $\mathrm{t}_{0}$ shares. If it sells those shares when the grant vests, it will receive $t_{0} P_{1}$, no portion of which is taxed. Therefore, the difference in the employer's wealth if the employee makes the election is $\left(t_{1}-t_{0}\right) P_{1}$. Thus, if the employer's tax rate rises over time $\left(t_{1}>t_{0}\right)$, it is hurt by the election, regardless of what happens to the price of the employer's stock. ${ }^{67}$ On the other hand, if the employer's tax rate falls over the vesting period $\left(t_{0}>t_{1}\right)$, it benefits from the election. ${ }^{68}$

When the employee's tax rate is constant and the employer's is rising, then both the employee and the employer are harmed by the election. In that case, the employee is unlikely to make the election and there is probably little need for the employer to prevent it. When, however, the employee's tax rate is constant and the employer's is falling, then the employer is better off with the election, whereas the employee is worse off. Moreover, if the expected decrease in the employer's tax rate is large enough, then the employer's gain will exceed the employee's loss, and so there will be a joint tax benefit from the election. However, in such circumstances, the employee would not voluntarily make the election. Thus, if the employer wants the employee to make the election, the employer must either require the employee to make the election as a condition of the grant or pay the employee to make it. ${ }^{69}$

67. If the employer's tax rate rises, it will receive less money when it sells the shares it purchased with its tax savings from the election, $t_{0} P_{1}$, than it would have received if the employee did not make the election, $t_{1} P_{1}$. In such a case, the employer's loss from the election is $\left(t_{0}-t_{1}\right) P_{1}$.

68. If the employer's tax rate falls, it can sell the stock it purchased with the proceeds of the election, $t_{0} P_{1}$, for more than the deduction would have been worth at the vesting date, $t_{1} P_{1}$, and so the employer is ahead by $\left(t_{0}-t_{1}\right) P_{1}$.

69. The text describes the net tax benefit (or cost) to the employee of electing as of the vesting date. The election however must be made within thirty days of the grant date, which is well before the stock vests. Thus, measured as of the grant date, the certainty equivalent benefit to the employer of the election can be rewritten as $(1+r)\left(t_{1}-t_{0}\right) P_{0}$, where 
The effects of a change in the employee's tax rate are in the opposite direction of those of the employer. Accordingly, the election is more attractive to the employee when her ordinary tax rate falls, and less attractive when it rises. ${ }^{70}$ The impact on the employee is also more complicated because the election in the base case harms the employee, but not the employer. Thus, in order for the election to become attractive to the employee her tax rate must rise substantially. When only the employee's tax rate is changing, the costs and benefits of the election are internalized to the employee and so she has the proper incentives to make the election. When, however, the employer's tax rate is also changing, the incentives are not all internalized.

\section{Restricted Stock Units}

The discussion so far has been for restricted stock. Some firms, including Microsoft, have taken to issuing restricted stock units to their employees. ${ }^{71}$ Restricted stock units differ from restricted stock in that the employer does not initially transfer shares to its employees. Instead, the employer makes an unfunded and unsecured promise to provide the shares at a specific date (delivery date), subsequent to the vesting date if those shares vest. Restricted stock units are thus unfunded, unsecured promises to deliver property in the future. They are therefore taxed under the rules that apply to other non-qualified deferred compensation. ${ }^{72}$ As such, the employee includes the value of her shares in ordinary income when she takes delivery, and, at that time, the employer deducts the same amount. ${ }^{73}$ Because restricted stock units (as opposed to the underlying stock) are not considered property, the $\S 83$ (b) election is not available. ${ }^{74}$ Firms issue restricted stock units as a means of deferring the tax consequences of the transaction to the employee beyond the vesting date to a later delivery date. ${ }^{75}$

$r$ is the after-tax interest rate over the period that the stock is not vested. From the base case, we know that the cost to the employee from the election measured at grant is $t_{p} P_{0}\left[(1+r) t_{C G}-1\right]$. Therefore, when the increase in the employer's tax rate is sufficiently large, it will offset the cost to the employee of electing. Specifically, this will occur when $\left(t_{t}-t_{0}\right)>t_{p}\left(t_{C G}-1 /(1+r)\right)$.

70. If she makes the election, she includes $P_{0}$ at the date of grant and pays tax of $t_{0} P_{0}$. At vesting, she has $\left(1-t_{C G}\right) P_{1}+t_{C G} P_{0}$. If the employee does not make the election, then she will include $P_{1}$ at vesting and pay tax of $\mathrm{t}_{1} \mathrm{P}_{1}$. If she does not make the election, then to equate her exposures, she buys $\left(t_{1}-t_{C G}\right) /\left(1-t_{C G}\right)$ shares and invests or borrows the excess, $\left[t_{0}\right.$ $\left.-\left(t_{1}-t_{C G}\right) /\left(1-t_{C G}\right)\right] P_{0}$. Thus, at vesting, she will have $\left(1-t_{C G}\right) P_{1}+t_{C G}\left[\left(t_{1}-t_{C G}\right) /\left(1-t_{C G}\right)\right] P_{0}+$ $\left[t_{0}-\left(t_{1}-t_{C G}\right) /\left(1-t_{C G}\right)\right] P_{0}(1+r)$. The difference in net worth at vesting is $\left[\left(1-t_{1}\right) /\left(1-t_{C G}\right)\right] t_{C G} P_{0}+$ $\left[t_{0}-\left(t_{1}-t_{C G}\right) /\left(1-t_{C G}\right)\right] P_{0}(1+r)$. The employee then is better off making the election when $t_{1}>$ $\left[t_{0}(1+r)\left(1-t_{C G}\right)+t_{C G} r\right]\left(1-t_{C G}\right) /\left(1+r-t_{C G}\right)$. This requires $t_{1}>t_{0}$.

71. Press Release, Microsoft Corp., Microsoft Reshapes Compensation for Continued Success (July 8, 2003), available at http://www.microsoft.com/presspass/press/2003/jul03/0708CompPR.mspx.

72. See I.R.C. $\$ 83(2005)$.

73. Id. § 83(b), (h).

74. See Treas. Reg. $\S 1.83-3(\mathrm{e})$ (as amended in 2005) (for purposes of $\S 83$, the term property excludes unfunded and unsecured promises to pay property in the future).

75. The American Jobs Creation Act of 2004, which made sweeping changes to deferred compensation rules, imposed additional restrictions on using restricted stock units to 
Since the units also defer the employer's deduction, it might be thought that it is more expensive for the firm to issue restricted stock units than restricted stock. However, as long as the employer's stock is publicly traded and its tax rate is constant, the employer is indifferent as to when it takes its deduction. That is because the employer can offset the effect of when it receives the deduction by trading in its own stock. ${ }^{76}$

Although the employer should be indifferent between issuing restricted stock and restricted stock units, the employee enjoys an additional tax benefit with the units. That is because the employee permanently escapes tax on the appreciation that occurs before she is taxed on the grant. Therefore, assuming that the employee sells her restricted stock units at delivery, and assuming that she would have sold the restricted stock on the same date, then the employee's incremental tax benefit from receiving restricted stock units instead of restricted stock is the avoidance of capital gains taxes on the appreciation that occurs between vesting and delivery. ${ }^{77}$ That benefit is also the parties' joint benefit because the employer's tax liability is not affected by the switch. ${ }^{78}$

\section{Forfeiture}

The discussion above has ignored the possibility of the employee forfeiting her restricted stock back to her employer. If an employee who has not made a $\S 83($ b) election forfeits her stock, she can claim an ordinary loss for what, if anything, she paid for that stock. ${ }^{79}$ If, however, the employee has made the $\S 83$ (b) election, and subsequently forfeits the stock, then she cannot claim a loss for her basis in the stock nor can she deduct the amount she previously included in income. ${ }^{80}$ She can only deduct the amount, if any, that she paid for the stock. ${ }^{81}$ Moreover, that loss is now a capital loss, not an ordinary loss. ${ }^{82}$ Thus, the possibility of forfeiture makes the election less attractive to employees for two reasons. First, an employee who has made the election cannot deduct the amount she previously included in income if she subsequently forfeits the stock.

defer taxes. See American Jobs Creation Act of 2004, Pub. L. No. 108-357, 118 Stat. 1418 (codified in scattered sections of 26 U.S.C.).

76. For example, if the firm issues restricted stock units, but would prefer the cash flow pattern from restricted stock with otherwise identical terms (and without the election), it can synthesize that pattern by selling $t$ shares at vesting for $t P_{1}$ and repurchasing those shares by using its tax savings at delivery.

77. A non-tax consequence of restricted stock units is that the units lock employees into their employers stock for a longer time (from vesting to delivery) than the corresponding stock. That will likely be seen as a cost to the employee and a benefit to the employer.

78. In terms of the numerical example, the incremental benefit from granting restricted stock units on 100 shares on July 1, 2004 that vest on July 1, 2007, but which are not delivered until July 1,2010, compared with granting restricted stock with the same terms (and so are delivered when they vest on July 1,2007) is that the employee permanently escapes tax on the appreciation that occurs between July 1, 2007, and July 1, 2010, on her 65 shares held after tax.

79. Treas. Reg. $\S 1.83-1(\mathrm{~b})(2)$ (as amended in 2003).

80. Id.

81. Id. § 1.83-2(a) (1978).

82. Id. 
Second, an employee who paid something for her stock (and receives less than that amount back upon forfeit) has a capital loss, whereas an employee who did not make the election has an ordinary loss.

In contrast with the employee who forfeited her stock, the employer who received a deduction because its employee made a $\$ 83(\mathrm{~b})$ election has to include the previous deduction in income if the stock is forfeited. ${ }^{83}$ If the employee did not make the election, there is no such inclusion. Thus, on the employer's side there is a small tax benefit from the election if there is a forfeiture. That benefit arises because the employer's deduction preceded its offsetting inclusion. Since the timing benefit to the employer is likely to be small, whereas the cost to the employee of the election if there is a forfeiture is likely to be large, the possibility of forfeiture is likely to reduce the attractiveness of the election to the employer and employee taken together.

\section{Explicit Payments for the Stock}

So far, the discussion in this part has assumed that the employee does not pay anything to her employer in exchange for her restricted stock. Although the overwhelming majority of employers do not require explicit payments in consideration of their grants of restricted stock, some employers do require such payments. ${ }^{84}$ This subpart thus extends the discussion of the $\S 83(\mathrm{~b})$ election by taking into account the possibility of the employer charging the employee something (possibly, but not necessarily, equal to the market value of the shares) in exchange for the shares. The principal result that arises from this analysis is that when the employee must make a payment, there can be a conflict of interest between the employer and the employee over the desirability of making the $\$ 83(\mathrm{~b})$ election. ${ }^{85}$

Denote by $B$, the amount the employee pays to her employer for one share of restricted stock. So far, we have assumed $B=0$. If the employer charges its employee the market price, then $B=P_{0}$. If the employer sells the stock to the employee at a discount, then $0<B<P_{0}{ }^{86}$

\section{a. Employer}

Start with the employer. When the employee pays nothing for her stock, the employer can offset the economic consequences of the $\S 83(\mathrm{~b})$ election by using the tax proceeds generated by the election to purchase additional shares. When, however, the employee pays something for her stock, the employer can no longer neutralize the economic effects of the

83. Id. $\S 1.83-6(\mathrm{c})$ (as amended in 2003).

84. See Blouin \& CARTER, supra note 33 , at 12-13.

85. The discussion in this subpart treats the explicit payment as outside of the parties' planning framework. That is obviously incomplete because the employer could charge more for the shares and pay a higher salary to compensate. The issues raised by making the payment explicit are discussed in Knoll, supra note 30.

86. I am not aware of any employers selling their stock as part of a restricted stock program at a premium. 
employee's election. Instead, the election hurts the employer. The logic behind that result is easiest to see when the employee pays the full market price for the restricted stock $\left(B=P_{0}\right)$. In that case, if the employee does not make the election, the employer will deduct the appreciation that occurs between grant and vesting, $\left(P_{1}-P_{0}\right) t$, which has a positive expected value. If, however, the employee makes the election, then the employer receives no tax deduction either at grant or vesting. Thus, when the employee pays the full market price, the election harms the employer by taking away the deduction for the appreciation that is expected to occur prior to vesting, $P_{0} t R$.

That same logic applies for any payment made by an employee to her employer for restricted stock. If the employee pays $B$ for one share, her purchase can be decomposed into paying the fair market value for $B / P_{0}$ shares and nothing for $\left(P_{0}-B\right) / P_{0}$ shares. Since the election has no effect on the employer when there is no explicit payment and prevents the employer from deducting the return until vesting when the employee pays the fair market value, the effect of the election is to deny the employer a deduction for the appreciation on the explicitly purchased portion of the grant. Thus, the employer's cost can be expressed as Btr. In other words, the cost to the employer of the election is losing its deduction $(t)$ on the anticipated return $(R)$ on that portion of the stock paid for by the employee $(B)$.

\section{b. Employee}

Turn now to the employee. She too finds that her view of the election is changed by the introduction of a payment for the restricted stock. Not surprisingly, the effect on the employee is the reverse of that on the employer. The election becomes more attractive to the employee the more she pays. Once again, the result is easiest to see when the employee pays the full market price. In that case, no immediate tax consequences arise from the grant and election, and any subsequent price changes prior to vesting (which have a positive expected value) are taxed at capital gains rather than ordinary tax rates. Thus, when the employee purchases the restricted stock at its fair market value, the election benefits the employee by reducing her tax on the appreciation that occurs through vesting by the capital gain preference. We know from the discussion of the base case that when she pays nothing for her shares, the election hurts the employee by subjecting the appreciation on her after-tax shares to capital gains taxes. Because any intermediate payment combines these two effects, the benefit to the employee of making the election, $\Delta(B)$, can be written as:

$$
\Delta(B)=B t_{P} R\left(1-t_{C G}\right)-P_{0}\left(1-t_{P}\right) t_{C G} R .
$$

The first term in equation (9) is the benefit to the employee of the election and the second term is the cost. The cost is the tax paid by the employee on the $\left(1-t_{P}\right)$ shares that would have been tax exempt had the employee not made the election, but which, as a result of the election, are 
now subject to capital gains taxes. The benefit is the after-tax return, $R\left(1-t_{C G}\right)$ on the tax savings from the payment. $\left(B t_{P}\right)$.

Consider two special cases. First, if the employee pays nothing for the stock $(B=0)$, the cost to the employee of making the election becomes $-\left(1-t_{P}\right) P_{0} R t_{C G}$, which is the cost of the election as derived in the base case. ${ }^{87}$ Second, if the restricted stock is purchased at the market price $\left(B=P_{0}\right)$, then the benefit to the employee from making the election becomes $P_{0}\left(t_{P}-t_{C G}\right) R$. That expression is readily amenable to an intuitive explanation. The benefit is the employee's tax savings (the difference between ordinary income and capital gains rates, $\left(t_{P}-t_{C G}\right)$ on the return from holding the stock over the vesting period, $P_{0} R$.

More generally, the parties will sometimes find that their private interests in the election conflict. For $B>0$, the employer is always worse off with the election, and the employee might be better or worse off. Moreover, increasing $B$ benefits the employee and harms the employer. Also, the employee is definitely better off making the election when $P_{0}=B$. Because there is a value for $B$, below $P_{0}$, at which the employee benefits from the election, ${ }^{88}$ such conflicts can arise for any set of tax rates with a capital gains preference. Moreover, the conflict between the parties will intensify as $B$ increases beyond that point. Although for any set of tax parameters with a capital gain preference there is always a range where the employee benefits from the election, there is not always a range $\left(0 \leq B \leq P_{0}\right)$ where the parties jointly benefit from the election.

Whether it is ever in the joint interest of the parties for the employee to make the $\S 83(\mathrm{~b})$ election depends upon the parties' tax rates. If the employee's capital gains preference, $t_{P}-t_{C G}$, exceeds the employer's corporate tax rate, $t\left(t_{p}-t_{C G},>t\right)$, then there is a value for $B\left(0 \leq B \leq P_{0}\right)$ above which the parties jointly benefit from the election. ${ }^{89}$ The intuition is that the benefit is the capital gain preference on appreciation between grant and vesting and the cost is the loss of the corporate tax deduction on that same return. If, however, the corporate tax rate exceeds the capital gain preference $\left(t>t_{P^{-}-t_{C G}}\right)$, then it is never in the joint interest of the parties for the employee to make the election..$^{90}$ Thus, for employers at the top statutory rate today, the election is never in the joint interest of the parties. ${ }^{91}$ For such firms, there is no tax benefit from making the election

87. See supra equation (8)

88. The employee benefits from the election whenever $B>P_{0}\left[\left(1-t_{P}\right) /\left(1-t_{C G}\right)\right]\left[t_{C G} / t_{P}\right]$, which will occur for a value of $B$ less than $P_{0}$ whenever $t_{P}>t_{C G}$.

89. This can be seen by rewriting the corporate tax rate, $t$. in terms of the capital gains preference, $t_{p}-t_{C G}$. Thus, $t=t_{p}-t_{C G} .+d$, where $\mathrm{d}$ is positive if the corporate tax rate exceeds the capital gain preference. At the current maximum statutory rates, $d$ is $15 \%$ because $.35[t]=.35\left[t_{p}\right]-.15\left[t_{C G}\right]+.15[d]$. Thus, the net gain from making the election,

$-B t+B t_{p}\left(1-t_{C G}\right)-P_{0}\left(1-t_{p}\right) t_{C G}$, can be rewritten and simplified as $-B d-\left(P_{0}-B\right) t_{C G}\left(1-t_{P}\right)$, which for $d<0$ is obviously negative for $B \leq P_{0}$.

90. The expression $-B d-\left(P_{0}-B\right) t_{C G}\left(1-t_{p}\right)$ is positive for some value of $B$ less than $P_{0}$ (that is, there can be a net gain from making the election) when $d$ is negative (indicating that the corporate tax rate is less than the capital gains preference).

91. That is because the capital gains preference, $20 \%=35 \%-15 \%$, is less than the corporate tax rate, $35 \%$. 
even if the payment is explicit.

\section{Stock not Publicly Traded}

In the base case, I repeatedly used the assumption that the employer's stock was publicly traded to derive the results. Specifically, I showed that the employer could offset both the tax and non-tax effects of the employee's $\S 83(\mathrm{~b})$ election by investing its tax proceeds generated by the employee's election in its own stock. Obviously, if the company cannot trade its own stock, it cannot neutralize the cash flow and capital structure consequences of the election. ${ }^{92}$ Accordingly, if the stock is not traded, the employer must do something other than repurchase its outstanding equity with the cash proceeds of the election. Under these circumstances, the employer will benefit from the election when its stock declines (or increases by only a small amount), and it makes a good investment with the cash. ${ }^{93}$ However, it is potentially misleading to describe any such gain or loss as a tax consequence of the election. It is more accurate to describe the result as a non-tax consequence of the employer's issuance of additional stock through the election. ${ }^{94}$

In addition, if the employer's stock is not publicly traded, the employee cannot increase her holdings of her employer's stock by purchasing more shares. ${ }^{95}$ If the employee cannot otherwise purchase shares, then the only way she can effectively increase her share holdings is by making the $\S 83($ b) election. Obviously, such an election will turn out well for the employee when the stock appreciates substantially and poorly when it does not. Once again, it seems misleading to describe whatever the result is as a tax consequence instead of as a non-tax consequence of the employee's election.

As described above, when the employer's stock is not publicly traded, the election does not have only tax consequences-it also has real conse-

92. I assume that the employer and employee cannot engage in private transactions with other shareholders to offset the effect of the election. If they can, because there are other willing parties with which to trade, the results are as in the base case.

93. The most reasonable and common assumption in the economic literature is that the employer can invest the funds in a project with an expected net present value of zero. I ignore issues arising from the transfer of value between equity-holders and creditors if the volatility of the new project does not match that of the firm. This phenomenon is called asset substitution.

94. Viewed from this perspective, the assumption that the stock is not publicly traded does not change the qualitative tax results-the election is still inefficient from a joint tax perspective. The hypothetical transactions that I used to isolate the tax consequences of the election were a heuristic designed to illustrate what, if any, was the tax cost of the election by equalizing the non-tax consequences. Even if these transactions are not feasible, the logic of the exercise still applies and the tax consequences are still as they were described above. The election exposes the appreciation that occurs prior to vesting to tax and is therefore jointly tax inefficient.

95. The employee might however be able to purchase additional shares from the employer. If so, then, as demonstrated for the base case above, the employee is better off purchasing additional shares from the employer than making the election. 
quences for both the employer and the employee. ${ }^{96}$ If the employer cannot repurchase its own stock, the election will, in effect, increase the number of shares the employer has outstanding, and it will increase the cash the employer must invest somewhere. Similarly, if the employee cannot buy additional shares of the employer's stock, then the election is the only way she can increase her share holdings. ${ }^{97}$

In effect, when the employee makes the $\S 83(\mathrm{~b})$ election, she is forcing the government to sell back to her some of the shares it holds through the individual income tax system. As described above in the discussion of the base case, the employee, in making the election, can be thought of as purchasing $t_{P}$ shares from the government and subjecting her original $\left(1-t_{P}\right)$ shares to capital gains tax. In addition, when the employee makes the election, she is, by that action, forcing the employer to sell $t$ shares to the government. Obviously, if the employee's personal tax rate on ordinary income and the employer's corporate tax rate are equal $\left(t_{p}=t\right)$, the employer's sale of shares equals the employee's purchase, and the parties are jointly worse off by the election, which exposes the original after-tax grant to capital gains tax. Alternatively, if the employee's personal tax rate exceeds the employer's corporate tax rate, the government is a net seller of shares. ${ }^{98}$ Thus, if the personal tax rate exceeds the corporate tax rate and the parties expect the firm's stock to appreciate sharply, then the election might be attractive to the parties jointly. ${ }^{99}$

The most obvious example where the parties expect the stock to appreciate substantially is when they report the value of the stock in an amount less than its current market value. Such a possibility is not plausible when the firm's stock is publicly traded, but it is when it is privately held. Assume the reported value of the stock is $D$, which might not equal the market value $P_{0}$. In order to hold the employer harmless for losing a deduction on the difference between $P_{0}$ and $D$, which would be worth $\left(P_{0}-D\right) t$, assume the employer reduces the employee's salary at grant by $\left(P_{0}-D\right) t /(1-t) .{ }^{100}$ As a result, all of the benefits and costs of undervaluing

96. The employer should be thought of as the other shareholders (and possibly creditors and other stakeholders) of the employer.

97. There is an obvious potential for conflict between employer and employee when the parties share expectations. If they expect the stock to sharply appreciate, the employer is hurt by issuing more shares and the employee benefits by purchasing more shares. Conversely, if they both expect the stock to fail to keep pace with the market (appropriately adjusted for risk), then the employer benefits by issuing more shares and the employee is hurt by buying more shares.

98. Furthermore, if the employer's corporate tax rate exceeds the employee's personal tax rate, the government is a net purchase of shares.

99. Also, if the corporate rate exceeds the personal rate and the parties expect the stock to underperform, the election might again be jointly attractive. The second possibility is remote both because given current statutory rates, there is little opportunity for $t-t_{p}$ to be very large, and restricted stock is unlikely to be used as compensation when the parties expect its price to fall.

100. The salary reduction exceeds the lost tax benefits by the factor $1 /(1-t)$ because the salary payment is deductible. 
the employer's stock and making the election go to the employee. ${ }^{101}$

When the stock was publicly traded, I derived the tax consequences of the election by first eliminating all non-tax consequences through a series of transactions. Such offsetting transactions would not be possible here, because the stock by hypothesis is not publicly traded. That is why the parties can claim that the stock's value is different than its market value. ${ }^{102}$ With that caveat, and solely in order to isolate the tax consequences, assume that it is hypothetically possible for the employer and employee to engage in such offsetting transactions at the market price while simultaneously declaring a value different than the market value. After such an exercise, the net benefit to the employee (and hence to the parties jointly) from undervaluing the stock and making the election is given by:

$$
\begin{gathered}
\Delta(D)=\left(P_{0}-D\right)\left(t_{P}-t_{C G}\right)+P_{0}\left(t_{P}-t_{C G}\right) R-D t_{P} R\left(1-t_{C G}\right)- \\
\left(P_{0}-D\right) t(1+r)\left(1-t_{P}\right) /(1-t) .
\end{gathered}
$$

The first term in equation (10) is the reduced tax on the undervalued shares; the second term is the reduced tax on the appreciation; the third term is the tax on the return from making the election; and the fourth term is the salary adjustment. ${ }^{103}$

Note that if the personal and corporate tax rates are equal, then it is always costly for the parties to undervalue the employer's stock and make the election. Thus, undervaluing the stock and making the election can be a jointly attractive strategy only when the personal tax rate exceeds the corporate rate. Accordingly, the tax benefit is at a maximum when both $\mathrm{t}=0$ and $\mathrm{D}=0$. In that case, equation (10) becomes $P_{0}\left(t_{p}-t_{C G}\right)(1+R)$, which has a ready interpretation. The maximum tax benefit from undervaluing the employee's stock and making the election is the product of the employee's capital gain preference and the expected value of the stock at vesting. Given current statutory rates, that is $20 \%$ of the stock's expected value at vesting. That gain can however be as large as $35 \%$ of the stock's expected value if the employee can avoid the capital gain tax. ${ }^{104}$ Thus, when the employer is effectively untaxed, the parties can generate a large tax benefit from undervaluing the employer's shares and making the election. ${ }^{105}$

101. The parties might choose to share the benefit between employer and employee. The assumption that the benefits redound to the employee is made to make the explanation clearer.

102. If the stock were publicly traded, it simply would not be feasible to report a different value under $\S 83$.

103. Note that if $P_{0}=D$, the first and last terms drop out leaving only the middle two terms. Those terms simplify to the cost of the election in the base case, $\left(1-t_{p}\right) P_{0} R_{C G}$.

104. The employee will avoid the capital gain tax if she holds the stock until her death (I.R.C. $\S 1014(\mathrm{a})$ ) or contributes the stock to charity (I.R.C. $\S 170$ ).

105. Why then do such employer's explicitly sell their shares to employees? Because the tax consequences are the same when the employee makes the election, whether the stock is priced explicitly or implicitly, there must be another reason. My guess is that a "sale" is being used to support the claim that the price paid is the market price. However, when sales are restricted and are part of a compensation package, such sales by themselves 
It is worth identifying the source of the parties' tax benefit from undervaluing the shares and making the election. The economic effect of the election is to force the government to sell some of its shares of the employer's stock to the employee at a below market price and to force the employer to sell some shares of its stock to the government at the same below market price. If the employer's tax rate is low enough relative to the employee's, then the $\$ 83$ (b) election will cause the government to sell more shares to the employee than it purchases from the employer. In that case, the benefit from the below-market transfers can exceed the cost from subjecting the after-tax grant to capital gains tax. Under those circumstances, the employer and employee jointly benefit from the undervaluation and election.

What about the incentive to either undervalue or overvalue the stock if the employee does not make the $\S 83(\mathrm{~b})$ election? Note that if the employee does not make the election, the value of the stock at the grant date will not have any tax consequences for the parties. Thus, the question becomes what incentives do the parties have for valuing the stock at vesting?

Consider the price at vesting (assuming that the employee has not made the $\S 83$ (b) election). For the employer, the only deduction it ever gets on the stock occurs at vesting and is equal to $\mathrm{tP}_{1}$. Thus, every dollar that the stock is undervalued costs the employer $t$. For the employee, the result depends upon how long she plans to hold the stock. Every dollar that the stock is undervalued converts a dollar of ordinary income into a dollar of capital gain and defers that gain from vesting until sale. If we denote the present value of the capital gains tax (as of the vesting date) by $t_{C G}^{*},{ }^{106}$ the employee's saving is $t_{P} t^{*}{ }_{C G}$. Thus, the joint benefit from undervaluing the employer's stock at the vesting date is $-t+t_{P}-t^{*}{ }_{C G}$. Hence, when $t_{C G}^{*}$ is close to the statutory tax rate $\left(t_{P}\right)$ and the personal and corporate tax rates are close together, the parties have an incentive to overvalue rather than undervalue the stock at vesting. Alternatively, when the employer's tax rate, $t$, is close to zero, there can be a strong incentive for the parties to undervalue the employer's stock. As described above, when the employer's tax rate is close to zero that can also provide the parties with an incentive to make the $\S 83(\mathrm{~b})$ election. ${ }^{107}$

\section{THE SECTION 83(b) ELECTION: THE OPTION TO WAIT}

The discussion, so far, has ignored the option to wait contained within $\S 83(\mathrm{~b})$. Section $83(\mathrm{~b})$ allows the employee up to thirty days to make the election. If the employee makes the election, she pays tax on the value of the grant as of the grant date, which is in effect equivalent to purchasing

do not establish an independent market price. There is however an incentive to use artificially low prices when the employer's effective marginal tax rate is low or zero.

106. If the stock were sold at vesting, then $t^{*}{ }_{C G}$ equals $t_{C G}$. If the statutory capital gains tax rate is constant, then $t^{*} c$ falls as the time until sale increases.

107. See supra notes 103-105 and accompanying text. 
additional shares. The election thus contains an option element because the new shares are not purchased at the market price at the time of the election, but rather at the price as of the grant date. More specifically, by making the election, the employee can purchase $\left(t_{P}-t_{C G}\right) /\left(1-t_{C G}\right)$ shares for $t_{P} P_{0}$. That is equivalent to purchasing the additional shares at a per share price of $\left[1+t_{C G}\left(1-t_{P}\right) /\left(t_{P}-t_{C G}\right)\right] P_{0}$. Since that is obviously more than $P_{0}$ (for $t_{C G}>0$ ), the option is initially out-of-the-money. ${ }^{108}$

All option contracts require at least two parties: the party that holds the option and the party that writes the option. The latter is often called the counterparty because its cash flow from the option is the mirror image of the first party's. With the $\S 83$ (b) election, the counterparty to the employee is not the employer, but the government. When the employee makes the election, the government, in effect, is forced to sell $\left(t_{P}-t_{C G}\right) /$ $\left(1-t_{C G}\right)$ shares back to the employee. That effective sale occurs because the government reduces its tax rate on the employee's shares from the ordinary tax rate to the capital gains tax rate. ${ }^{109}$

The employer has also written an option. Although triggered by the employee's election, the employer's counterparty is not the employee, but the government. Moreover, the option written by the employer does not mirror the employee's held option, either in terms of the number of shares covered or their stock price. The employer has written an option to sell $t_{P}$ shares of the employer's stock for $t_{P} P_{0}$. Thus, the employer's option is said to be at-the-money initially. ${ }^{110}$

As with any held call, the employee's optimal strategy is usually to hold the option until right before it expires and then decide whether or not to exercise. ${ }^{111}$ Because the employee's option is initially out-of-the-money, the price of the stock must rise for the employee to find its exercise desirable. If the stock price is below the exercise price when the option expires, the option will expire without ever being exercised. As with call options generally, the option is more valuable the more volatile the price of the underlying stock and the longer the time until expiration (which by statute is no longer than thirty days).

How much is the thirty-day option worth to the typical employee? Given current statutory tax rates, the strike price is roughly $50 \%$ above the grant price. ${ }^{112}$ Thus, for it to make sense for the employee to exercise

108. It is cheaper for the employee to purchase the shares directly on her personal account than indirectly through the election because the election exposes the return on $\left(1-t_{p}\right)$ shares that would not have been taxed until vesting to capital gains taxes when they are sold. It is that cost that accounts for the difference between the option's exercise price and the market price of the stock at grant.

109. The government originally obtained these shares through the tax system. By imposing a tax of $t_{p}$ on the employee and including the grant within income at vesting, the government in effect required the employee to transfer $t_{p}$ shares to it.

110. The difference in the strike prices goes to the federal government, which can $\operatorname{tax}$ the return on $\left(1-t_{p}\right)$ shares at the rate of $t_{C G}$ only if the employee makes the election. .

111. The principal exception is when the stock pays dividends, which $I$ have assumed throughout this Article does not occur.

112. The strike price is $\left.\left[1+t_{p}\right) /\left(t_{p}-t_{C G}\right)\right] P_{0}$. For $t_{y}=0.15$ and $t_{p}=0.35$, the strike price is $1.4875 P_{0}$. 
her option, the stock price must increase by roughly $50 \%$ over the first month. That is unlikely to occur often and so the value of the option to wait before making the election is likely to be small. For example, a typical NASDAQ company has an annual volatility for its stock price of about $60 \% .113$ The Black-Scholes value of a one month call option with a strike price $50 \%$ above the current market price and an annual volatility of $60 \%$ is less than $.1 \%$ of the share price. That is to say, a one-month call option on one share with a current market price of $\$ 100$, a strike price of $\$ 150$, and an annual volatility of $60 \%$, is worth less than ten cents. However, as the capital gains rate declines, the strike price falls. For $t_{C G}=0$, the option is issued at-the-money and any increase will suffice. Of course, one way for the employee to reduce her capital gains tax rate, which is the effective tax rate (not the statutory tax rate), is to extend her holding period on the stock. If she plans to hold the stock until death (or contribute it to charity), the appreciation is never taxed and so the effective capital gains tax rate is zero. For such a grantee, the value of the option to wait is worth about $7 \%$ of the share price, or roughly $\$ 7$ on each share of $\$ 100$ restricted stock.

What then are the practical implications of the insight that $\S 83(\mathrm{~b})$ provides the employee with an option to wait? Given current statutory tax rates, for many employees, that option is nearly valueless. Although employees could drive down their exercise prices by holding onto their stock for long periods after vesting, there is a real economic cost to the employee in terms of increased exposure to the risks of holding her firm's stock-a risk to which most employees are already overexposed. There are however two groups who might find the option to wait valuable. The first are members of the employer's board of directors, especially directors with substantial private wealth, who are employed elsewhere, and who serve on numerous boards. Such people are better able to diversify the risk from holding the additional shares for long periods of time. ${ }^{114}$ The second group consists of grantees who intend to contribute their shares to charity. Because such stock is never subject to capital gains tax, such an employee should treat the option as if it were granted at-themoney.

Although I have not seen any hard data, it is my understanding that most employers ignore the employee's option to wait. Given the option's high strike price and short maturity, the employee's option has little value in most cases. Nonetheless, for employers paying corporate income tax at $34 \%$ or $35 \%$, the employee's option, if exercised, will usually cost the

113. Note however that anyone who planned to hold the stock indefinitely, would still have to pay personal level capital gain tax if the employer was acquired in a taxable transaction. Thus, the holder is not assured of a zero tax rate.

114. The employer's cost and employee's benefit are equal when the employer's tax rate equals the employee's capital gain preference, which for employers and employees in their top statutory brackets requires that $t_{C C}=0$. 
employer more than the employee benefits. ${ }^{115}$ Thus, when viewed from a joint perspective, the option to wait is generally harmful to the parties taken together.

The employer has several alternatives available to it if it wants to rein in the employee's option to wait. ${ }^{116}$ If the employer does not want to transfer additional value to the employee, it could simply eliminate the employee's option to wait by requiring the recipient to commit in advance of receiving her shares either to make the election or not. ${ }^{117}$ Alternatively, if the employer's concern was not with transferring value to its employee, but with the fact that much of that value goes to the government, ${ }^{118}$ it could prohibit the employee from making the election (or at least waiting to make the election) and offer to sell her a fixed amount of additional shares anytime during the month at a set price. In effect, the employer would write the option explicitly, not implicitly through the tax law. That would create an additional benefit for the parties to share.

\section{Conclusion}

Restricted stock is well on its way to becoming, along with ESOs, one of the two dominant forms of equity-based pay. Yet in spite of both its importance and prominence, little attention has been paid to the question how firms should design their restricted stock grants in light of taxes. By employing a joint parties perspective and separating tax from non-tax consequences, I have begun to answer that question. Along the way, I have identified one issue that has heretofore been ignored in the literature and expanded on another that has previously been identified, but which was examined incompletely. ${ }^{119}$

First, I have looked at the employee's option under $\S 83$ (b) to treat the grant as if it vests immediately for tax purposes. In contrast with prior authors, who have considered this election solely from the perspective of the employee, I have taken a joint perspective. Such a perspective is appropriate because the employer can-as a condition of the grant-require, prohibit or otherwise restrict the election. Starting with the employer, if there is no explicit payment for the restricted stock, the employer can offset both the tax and non-tax consequences of the employee's election by using the proceeds of the election to buy back its own stock. In such circumstances, the tax consequences of the election to the parties depends solely upon the consequences to the employee. For the

115. See Hall, supra note 1 for data on the volatility of stocks trading on different exchanges.

116. Only if the employer's tax rate is very low will the employee's tax benefit exceed the employer's cost.

117. This possibility is suggested by Treasury Regulation $\S 1.83-2$ (b) (1978) (stating that the election may be filed prior to the date of transfer).

118. If the option is exercised, the employer loses more than the employee benefits (for $t_{C G}>0$ and $\left.t=t_{p}\right)$.

119. I have also identified the issue whether the employer should charge the employee for her restricted shares explicitly or implicitly. That issue is not discussed in this Article. 
employee, the election is undesirable because it exposes the after-tax grant to tax from the vesting date. (In contrast, if the employee bought shares directly, she could purchase the same number of shares for the same amount without exposing her original grant to tax.) In such circumstances, the election does not make sense for the employee alone or the parties jointly.

Second, I have identified the employee's option to wait thirty days before making the $\S 83$ (b) election. For employees in or near the top personal income tax bracket and who expect to pay capital gains taxes on the grant in the not too distant future, the strike price is so high (about $150 \%$ of the grant price) that the option is likely to have little value. However, for grantees who can avoid or at least substantially defer their capital gain taxes, the strike price is close to the grant price and the option is worth about $7 \%$ of the grant for a typical NASDAQ company. In addition, if the employer is paying taxes at $34 \%$ or $35 \%$, the employer is likely to lose more from the option if it is exercised than the employee will gain.

Finally, most of the discussion in this Article-including the conclusion-has been at the level of the trees. Looked at as a forest, the lesson that should be drawn from this Article is that there can be significant value added by integrating tax planning into the design of equity-based pay programs. That, however, needs to be done carefully. It requires an all-parties perspective. It also entails a counterfactual exercise that isolates the tax consequences of an action through a series of hypothetical transactions. Finally, it requires consideration of the non-tax consequences of any action that cannot be eliminated. That is not how most tax planners approach tax planning issues today, but it should be. 